\title{
COMMUNITY PARTICIPATION OF TEMUKU AYA SUBAK TOUR DEVELOPMENT IN VILLAGE OF TAJEN, PENEBEL DISTRICT, TABANAN REGENCY
}

\author{
Gusti Ayu Putu Indah Trisna Dewi, I Wayan Pantiyasa \\ The International Bali Tourism Institute \\ Indah.dewi995@gmail.com,pantiyasawayan@yahoo.com
}

\section{ABSTRACT}

The purpose of this research was to know the tourism potential of Temuku Aya Subak Tour seen from 3A that were an attraction, access, and facility. In addition, to know the participation of local communities, as well as the impact of Temuku Aya Subak Tour development to the local community. Temuku Aya Subak Tour is located in Tajen Village and developed by local people who see the potential of tourism in this village.

Data collection techniques used were in-depth interviews, observation, and documentation. The analysis technique used was descriptive qualitative analysis and also Triangulation data. The results showed Temuku Aya Subak Tour had the potential of natural rice fields and plantations. Temuku Aya Subak Tour also offered tourism activities as well as the preservation of local culture and traditions. In addition, local communities also participated as investors and as employees in the development of Temuku Aya Subak Tour. The tour economic impact could provide employment. From the socio-cultural impact, it could keep the local customs and traditions of the village, and from environmental impact, the local community could be more aware of the cleanliness of the village environment.

Keywords: tourist attraction, tourism potential, community participation, tourism impact 


\section{Introduction}

The Tourism sector is one of the most important sectors of a country. In addition to increasing revenue, the development of tourism will also be able to increase the provision of jobs, increase tourist visits, and will also be able to develop areas that have tourism potential. Bali is one of the most visited tourist destinations in Indonesia. Almost every district in Bali has its own tourism potential to be developed. The world has also learned that the art of Balinese culture inspired by Hinduism is truly remarkable, of high value and unique, to the extent that its beautiful nature and cultural arts are Bali dubbed "A Piece of the Land of Heaven that Falls to Earth" (Bali Travel Newspaper, 2016). Associated with the nickname that contains such praise, the people of Bali should be proud and at the same time must be responsible for the preservation of nature and Balinese cultural arts which is the heritage of ancestors.

The number of foreign and domestic tourists who choose to spend the time to visit Bali and also travel in Bali it certainly can increase the income of Bali itself. With the development of tourism in Bali, various efforts made by the Government District/City to develop the potential of tourism in an area into a tourist destination or one of the tourist destinations. Development of tourist attraction in an area by involving the surrounding community will have a positive impact for the community itself and also the region, because if the tourist attraction is managed properly and can help improve the economy of the surrounding community and also contribute to the region. The development of the tourist village is an alternative tourism that is able to empower the community, so it can be the subject of tourism development (Bali Travel Newspaper, 2016). Bali Provincial Government for the year 2016 re-developed 11 tourist villages spread across eight districts, it is as one effort to improve the welfare of village communities (Antara News, 2016). Balinese hospitality attitude is also one of the influences of the development of tourism in Bali well, therefore tourists feel comfortable when traveling to Bali. Unspoiled natural condition with beautiful rice field scenery is located in one of the regencies in Bali that is in Tabanan regency. The natural beauty of the rice fields in Tabanan regency makes investors glance at the opportunity to develop nature-based tourist paddy fields. Most of the 
people must already know the tourism object of Jatiluwih Village which has beautiful scenery with terraced paddy fields or often called terraces and also has been designated as world cultural heritage by UNESCO (United Nations Educational, Scientific and Cultural Organization).

However, in one village named Tajen Village also has a natural potential that offers views of rice fields are still beautiful. The expanse of rice field is quite wide in the village of Tajen is also due to the livelihood of local communities are mostly farmers. Nature tourism based rice fields can be developed in the Tajen Village, Penebel District, Tabanan. The potential of this village, which is still paddy fields with subak system, besides the beautiful scenery of the countryside, the unique traditions of piwit nandur (the process of rice cultivation), cultural potentials such as religious ceremonies at temples, has a traditional dance that is Baris Tujeng, a sacred dances and danced at the ceremony of Ngaben. With those potential, then in this Tajen Village has developed a village tour called Temuku Aya Subak Tour. At the beginning of the plan Temuku Aya Subak Tour formation, the first thing to do is to hold meetings and conduct deliberations with community leaders and eventually form a group. After holding a meeting and deliberation then this group determines the agreed and appropriate name that is Temuku Aya Subak Tour. Name Temuku Aya Subak Tour has a meaning that is believed by the local community, Temuku Aya means a fair division. If in terms of rice field or subak system in Bali the meaning of Temuku Aya itself is better known as fair and equitable water distribution. So as the name agreed, it is expected that the development of Temuku Aya Subak Tour will be able to run well and smoothly so as to bring benefits to the community. The benefits obtained can be distributed fairly and equitably so that all can earn benefit from the development of Temuku Aya Subak Tour.

In addition to supporting from community leaders and also stakeholders of Tajen Village itself, development of Temuku Aya Subak Tour also gets support from subak. Subak is a community organization that specifically regulates the irrigation system of rice fields used in suitable rice planting in Bali. Therefore, the development of Temuku Aya Subak Tour features a panoramic view and the natural potential of rice fields. The activities presented by Temuku Aya Subak 
Tour are trekking, cycling, see the farmers or participate directly in the activities of metekap (plowing rice fields), see people directly play rindik (traditional musical instruments), see the making of wicker or typical Balinese crafts, making traditional cuisine (cooking class), see the process of pounding rice to become rice in the traditional way, and also majejaitan (making offerings or ceremonial facilities) after doing all the activities, then enjoy a dish of typical cuisine by Temuku Aya Subak Tour. In addition to forming a group for Temuku Aya Subak Tour, the board of Temuku Aya Subak Tour also formed a group of environmental care. The purpose of the establishment of the group is to care and preserve the environment in the village of Tajen itself, and also because Temuku Aya Subak Tour in Tajen Village is being developed in earnest, then the environment must also be considered cleanliness. Development of Temuku Aya Subak Tour is also fully supported by community figures to be able to run programs that have been designed. If it is going well and can bring new profits to the board of Temuku Aya Subak Tour, they will conduct a consultation again with the community leaders, so that village also can feel the benefits of this tourism development. For the promotion process itself, the board and members of the group Temuku Aya Subak Tour are trying to establish cooperation with ITDC (Indonesia Tourism Development Corporation).

At the opening of Temuku Aya Subak Tour also invited Senator DPD RI Dr. Shri I Gusti Ngurah Arya Wedakarna. He came directly to open Temuku Aya Subak Tour as well as provide full support and encouragement in the development of nature-based tourism rice fields that still maintain its sustainability. In addition, the board members of the Temuku Aya Subak Tour group succeeded in bringing IESCO (International Ecological Safety Collaborative Organization) representatives from China to visit Temuku Aya Subak Tour. Organizational structure/management for Temuku Aya Subak Tour was also formed on November 08, 2016. Inauguration letter group Temuku Aya Subak Tour has been made by the village head and will be confirmed also to the Regent of Tabanan, so that Tabanan Tourism Office and Tabanan Regency in particular to note that in Tajen Village has a group engaged in tourism. In addition, the group of Temuku Aya Subak Tour is requesting coaching from the Department of Tourism. In the 
development of Temuku Aya Subak Tour is there a very important involvement of the local community, tourism activities presented by Temuku Aya Subak Tour is primarily the workforce of the local community such as tour guides, food providers, food and drink waiters, attractions at the time of farmers metekap (plowing rice fields), teachers at the time of cooking class, wicker makers, teachers to make ceremonial facilities and others it is the local community of Tajen Village itself.

Because Temuku Aya Subak Tour is still in a new stage developed then the people involved in tourism activities is willing to be given wages or salary in accordance with the agreement. Because the most important, Temuku Aya Subak Tour can run if it has developed and brought in new profits will conduct deliberations to discuss their welfare. In addition to the participation of the local community of investors who are local communities of Tajen Village itself, also has an important role in the development of the Temuku Aya Subak Tour. The role is as the coordinator/coaching board, chairman, secretary, treasurer, and members. In addition, to be able to run this group then reappointed 4 people from the investor to be operational. To be responsible can operationalize or manage the Temuku Aya Subak Tour. In addition, all members are also responsible for promoting word of mouth, through brochures, in social media, in organizations, at work or otherwise. Facilities that are available in Temuku Aya Subak Tour such as men's and women's toilets, hand washing, foot wash, bicycle parking, and places to eat. Access to Temuku Aya Subak Tour passes the path that can only be passed by motorcycle and bicycle, it is because the road is only crossing by the farmers who go to the rice fields and farmers who bring their results of farming, besides that considering the importance of preserving rice fields and also the natural surroundings.

The purpose of development Temuku Aya Subak Tour is in addition to providing welfare to the local community, also aims to build the village and also introduced the village of Tajen in particular and Tabanan district generally national or international level but it is also expected the preservation of Balinese culture from the activities presented in Temuku Aya Subak Tour. Without being aware of the development of tourism has an impact on the village of Tajen itself. 
With the development of Temuku Aya Subak Tour is the cleanliness of the village environment must be considered and cleanliness must be maintained so that tourists who visit feel comfortable. As the development of Temuku Aya Subak Tour is undeniable it will have an impact on economic development especially on Temuku Aya Subak Tour and also Tajen Village itself. Impacts on Socio-Culture will also be felt in this village as changes in the mindset of a more modern society but still uphold the norms of religion. There is also a possibility that the livelihoods of local people will also be involved in tourism.

\section{THEORITICAL REVIEW}

\section{Tourism Potential}

Yoeti (2002) argues that the success of a tourist attraction to the achievement of tourist areas is very dependent on $3 \mathrm{~A}$, the attraction, access, and amenities. While Sujali in Amdani (2008) mentions the tourism potential as a capability in a region that may be utilized for development, covering nature and human as well as the work of man himself. As for the various tourism, potentials are divided into three, namely as follows: 1) Natural Tourism Potential, which is a natural tourism potential is a state, type of flora and fauna of an area, landscapes such as beaches, forests, mountains and others (state physical area). 2) Cultural Tourism Potential, which is meant by cultural tourism potency is all result of creativity, taste and human initiative either in the form of customs, handicrafts, arts, historical relics in the form of buildings, for example, monument. 3) Manmade Tourism Potential, in the form of dance performances, performances or cultural arts performances in an area.

\section{Society Participation}

Adisasmita (2006) states that participation is defined as the initiative, participation, and involvement of all members of the community in decisionmaking, the formulation of plans and development programs that the local community needs, its implementation and monitoring and supervision. This is to improve people's welfare. Participation of community members is the involvement of community members in development including activities in the 
planning and implementation of development programs including activities in the planning and implementation of development programs undertaken within the local community. In this case the involvement and participation of local communities in the development of tourist attraction Temuku Aya Subak Tour that can provide benefits to the community itself. If in the tourism development of the local community is involved, in addition to providing benefits to the community itself will provide the impact of sustainable tourism development as well as the tourist attraction. Therefore the role and support of local communities are very important in the progress of every tourist attraction that is being developed.

Ointoe, et.al (2005) mentions literally, participation means participating in an activity. Participation can be broadly defined as an active and voluntary form of community involvement and participation, both for reasons of intrinsic and extrinsic in the whole process of the activity. According to Prayogo (1976) in Mulyadi (2009) mentions in the development of tourism, community participation is divided into two types, namely: 1) Direct participation is the conscious participation of the community which is directed to develop tourism, including the development of mutual assistance, involvement in tourism entrepreneurs or through the development of a sense of belonging among the community by the government. 2) Indirect participation is participation that is indirectly in contact with tourism activities. Individual communities do not directly get contributions from tourism activities through maintenance of environmental hygiene, the promotion of quality art and culture, beauty coaching and personal development.

\section{Impact of Tourism Development}

In the development of tourism in a region will have an impact on the economic development of local communities. The economic impact can be positive or negative in every development of tourism object. On the positive side of this economic impact, there is direct and some are not direct. The immediate positive impact is to create new jobs for local communities, whether as employees of the cleanliness, security, or others that match the skills, skills of the surrounding community. While the indirect economic impact is the progress of 
thinking about the development of a tourist attraction, the emancipation of women so that women can work. Cohen (1984) in Ismayanti (2010) adds that the impact of tourism on the economy can be positive and can be negative. In general, these impacts can be grouped as follows: Impact on foreign exchange earnings, impact on community incomes, impact on employment opportunities, impact on prices and tariffs, impact on the distribution of benefits and benefits, impact on ownership and control, impact on development, of government revenue. The economic impacts felt by the people with tourism is the availability of employment, the increasing welfare of society, the increase of income, and also the increase of education. In addition to the economic impact, in the development of tourism also have an impact on Social Culture. According to Wall (1982) in Ismayanti (2010) said the impact of tourism on social culture is said to be people impact because it is related to the influence to the people, the host, and the tourists in changing the quality of life, both positively and negatively. Changes in the quality of life that is like the attitude of society, the feeling of society when entry the tourism, and also the living conditions of society. Social and Cultural Impacts arise when there is an interaction between tourists and the community when: a) Tourists need tourist products and buy them from the public. b) Both (tourists and the community) are both doing tourism activities. For example, both are traveling by the beach or both are watching the local arts entertainment. c) Both meet face to face and exchange information or ideas. For example, the community becomes a guide for tourists. The nature of the tourist-community relationships that cause the impact of tourism on socio-cultural become unique. The impact that is also generated in the development of tourism is the impact on the environment. Ismayanti (2010) said, the tourism industry has a close relationship and strong with the physical environment. The natural environment is a tourism asset and is impacted by the nature of its physical environment is fragile and inseparability. Is fragile because the natural environment is a creation of God that if destroyed not necessarily will grow or return as before. Is inseparable because humans must come to the natural environment to be able to enjoy it. In theory, the relationship of the natural environment with tourism must be mutual and useful. Tourists enjoy the natural beauty and income paid tourists are used to protecting and maintain 
nature for the sustainability of tourism. Therefore with the tourism, awaken the community to conserve the environment, keep the environment clean, cultivate for future sustainability.

\section{RESEARCH METHODS}

The place of research was conducted in Tabanan area precisely in the village of Tajen, Penebel District, Tabanan Regency. Tajen village is located about $45 \mathrm{~km}$ if taken from Denpasar City. Temuku Aya Subak Tour precisely located at Jalan Merpati, Banjar Tajen Jeroan. The cool climate and weather also the slope of sloping land from the mountains on the north side to the coastal areas on the south make Tabanan very superior in terms of wetland farming and plantations. North Tabanan, start from Bedugul area is a producer of fruits and vegetables while the middle and southern Tabanan is a producer of good quality rice. In accordance with its natural conditions, Tabanan promotes natural and agricultural tourism as its superior potential in tourism. This Tajen village was chosen by the researchers because this place has the potential of natural tourism of rice fields and also cultural tourism to be developed. Therefore, the local community at the same time has an idea to develop a village tour called Temuku Aya Subak Tour. The potential of the natural potential of rice fields and at the same time introduce to tourists the activities of farmers in the paddies and also trying to introduce the traditional culture of Bali.

The data type of this research is quantitative data and qualitative data. Quantitative data is all information collected from the field which is expressed in numerical form or incubated according to Pantiyasa (2013). Qualitative data is data that is not in the form of numbers but in the form of information, according to Pantiyasa (2013). The data source for this research is primary data and secondary data. Data collection techniques used in this study are documentation, in-depth interviews, and observation. Data analysis techniques in this study using qualitative descriptive analysis techniques. Bogdan and Biklen (2007) in Gunawan (2016) suggest that qualitative descriptive data analysis is the process of systematically searching and arranging the results of interviews, records, and collected materials to improve understanding of all things collected and enable to 
present what is found. This research technique also uses Data Triangulation Technique. According to Nasution (2003) Triangulation can be used by using different techniques of interview, observation, and documentation. This triangulation besides being used to check the truth of the data is also done to enrich the data. In this study, the data sought such as tourism potential, participation, and the impact of Temuku Aya Subak Tour development in the field will be collected and then will be identified to produce a conclusion.

\section{RESULTS AND DISCUSSION}

The development of Temuku Aya Subak Tour in Tajen Village, Penebel Sub-district, Tabanan Regency is one of the steps to be able to introduce the potentials owned by this village. Temuku Aya Subak Tour has the potential of natural rice fields and also plantations, Temuku Aya Subak Tour itself precisely located in a stretch area of rice fields. Therefore, tourists can enjoy the natural atmosphere of rice fields which are still beautiful and cool. Potential of natural rice fields is become an icon in Temuku Aya Subak Tour because of this village as one of the rice producers in Tabanan regency. Tabanan regency also has a nickname as a "rice barn" in Bali, as many wetland farms grow well and produce good quality farm product. With the development of tourism in Bali which has an impact on the increase of income in Bali province, so every area in Bali competes to explore the potential that exists in each area. So also with the potential in this village of Tajen. The local villagers develop a village tour that is Temuku Aya Subak Tour is to be able to introduce to the tourists that in this Tajen Village has the potential of natural tourist rice fields that are not less interesting with other tourist attraction.

In this Tajen village, most of the people's livelihood is as farmers. According to the village profile of Tajen that researchers read there are 689 people, local villagers who work as farmers. Means there are about $50 \%$ of local people who still pursue farming for sustainability. Therefore, it is closely related to the preservation of the area in this village of Tajen. The local community is a friendly society and upholds a sense of kinship. This is evident if there are religious ceremonies or traditional ceremonies, the community still keeps the 
ceremonial means in mutual cooperation and together or in Bali term is called ngayah. Tourism activities offered by the attraction of this tour is an activity associated with the activities in the wild rice fields and also the traditions of local communities.

\section{Tourism Potential of Temuku Aya Subak Tour}

With the development of Temuku Aya Subak Tour, according to Yoeti (2002) that the success of a tourist attraction to the achievement of tourist areas is very dependent on $3 \mathrm{~A}$ of attraction, accessibility, and amenities. In the development of Temuku Aya Subak Tour, three things to watch out for are attractions, access, and also accommodation.

\section{a) Attraction}

In the development of Temuku Aya Subak Tour tourist attraction is offered the nature tourism of rice fields for the attractions such as cycling and trekking surround the natural rice fields. If tourists are interested to do cycling, Temuku Aya Subak Tour already has 10 bikes provided for tourists. If tourists do trekking activities from Temuku Aya Subak Tour, they have provided wooden sticks and also typical Balinese hat made of woven bamboo. Potential owned is the natural tourist potential of rice fields and plantations. The Excellence of Temuku Aya Subak Tour is far from the crowds of residential residents and the only visible expanse of rice fields and plantation residents. In addition to the cultural attractions presented by Temuku Aya Subak Tour are majejaitan (making offerings or ceremonial facilities), see people directly play rindik (traditional musical instruments), see the making of wicker or typical Balinese crafts, making traditional cuisine (cooking class), and also can see the process of making rice with the traditional way of pounding rice. In addition there are also other tourist attraction activities such as: metekap (plowing rice fields) using buffalo and also nandur (planted rice) in the rice field of Temuku Aya Subak Tour. It was done to indirectly can introduce the customs of local communities and also the ancestral culture which is still applied and still preserved by the people in this village until now. Temuku Aya Subak Tour is exactly located in the rice fields in Banjar Tajen Jeroan. Because the location of Temuku Aya Subak Tour is located in the rice fields and also among the plantations, then Temuku Aya Subak Tour has a future 
potentially developed civet coffee. And the plan of this civet coffee attraction development will be presented to tourists from the beginning of the civet coffee produces up to the process of making and in the end can be presented and enjoyed by tourists who visit. Future plans will also be developed bee honey cultivation, because in Temuku Aya Subak Tour there is a new one and only bee house, the plan is the honey bee house in cultivation will be empowered and will be presented to tourists.

b) Accessibility

Access to Temuku Aya Subak Tour is quite good and can be reached by car and also elves only. If using a big bus it's will not enough, because the road to Temuku Aya Subak Tour uses concrete and does not use asphalt so the road is not so big. If there are two cars bumped anyone must be succumbed to find a rather broad road in order to be able to pass. But for the main road in the village of Tajen is already using asphalt. To arrive at Temuku Aya Subak Tour, the car or elf parked first in the parking area which is already provided. Parking land provided is also not so vast, it has not been able to accommodate the number of vehicles that many. If the vehicle has been parked, then to arrive at the location of Temuku Aya Subak Tour the tourists must walk or use mountain bikes that pass through the river as a river that irrigates the rice fields and also through community plantations. Because the road to be traveled by tourists is a trail that has been concreted. This is done in order to maintain the beauty and sustainability of natural rice field communities around the area of Temuku Aya Subak Tour.

c) Amenities

Facilities provided by Temuku Aya Subak Tour is a restaurant that has a view of rice fields, and also other public facilities such as parking, toilets, hand washing, and foot wash. In addition, there is also provided P3K to anticipate if there are things that are not desirable. Local people are also involved as a waitress, cook, guide who pick up guests and also as a tour guide. Because Temuku Aya Subak Tour is newly developed so it has not been provided by the homestay or villa area, it is also due around Temuku Aya Subak Tour is a land that is still productive. That scene from the current development of tourism potential in Temuku Aya Subak Tour is very potential for future development. 
Even the chairman of Temuku Aya Subak Tour said that if the future of this development has been running well and smoothly, it is possible to cooperate with the community for homestays or to find unproductive land that will be built homestay.

\section{Community Participation in the Development of Temuku Aya Subak Tour}

In the development of Temuku Aya Subak Tour also required the role or participation of the local community. Because tourism development will work well if there is support from the local community. According to Prayogo (1976) in Mulyadi (2009) Community participation is divided into two types, namely direct and indirect participation. Direct participation of local people as the originator of ideas in the development of tourism in this village, some people already have experience in the field of tourism and see the potential in this village is considered to have opportunities to develop. The community also participated as investors in developing the Temuku Aya Subak Tour. The people who become investors are 22 people. All investors are included in the organizational structure of Temuku Aya Subak Tour, as for the organizational structure that is as the coach, chairman, vice chairman, secretary, deputy secretary, treasurer, deputy treasurer and members. In addition, the local community is also involved as an employee which is a waitress to serve tourists during meals, guide to guides the tourists while doing tours, cooks to make and prepare food for tourists, in absorbing the workforce, the Temuku Aya Subak Tour prioritize local communities who have experience in tourism as an employee. Because Temuku Aya Subak Tour has only been running for almost a year, it has not been much in employee recruitment. The number of existing employees at this time are 1 person waitress, 2 cooks, and 3 guides. In addition, if tourists want to do the natural attractions such as plowing rice fields, they will be searched farmers who are experts in plowing the fields for them. And also if tourists want to plant rice then will be searched also farmers who are experienced in planting the rice.

Indirect participation by the community is like the village head and other village leaders. Because the characters only provide support and also give permission for Temuku Aya Subak Tour can run. The community figures also provide suggestions for Temuku Aya Subak Tour so that can run well and 
smoothly. In order to provide a positive impact on the village later. These communities participate indirectly in maintaining the cleanliness of the village environment as well as the security of the village environment. Because local villagers live side by side and also respect each other. That way tourists who visit feel comfortable.

\section{Development Impact of Temuku Aya Subak Tour to Society}

1) Economic Impact

In the development of tourism in an area will definitely have an impact on that area. One of the impacts is the economic impact. One of the real impacts that can be felt directly by the local community is to create jobs for the community. With the development of Temuku Aya Subak Tour provides additional income for the communities involved. Although the income is not too big, the management of Temuku Aya Subak Tour is trying to keep improving to be better in the future and bring profits. The development of Temuku Aya Subak Tour has a very good impact for the village, by the development of tourism in this village can further introduce the village of Tajen and also introduce the subak itself. With the development of this tour has an impact on the quality of community life such as the level of community education. If according to government regulations the children must be compulsory for up to 9 years. In the village of Tajen itself young people who have completed their education in high school (SMA) are around 70\% and who continue to higher level like D1-S2 about 30\% only. Most of them after finishing high school education to seek immediate job seekers. With the development of tourism the young people want to add more ability and determined to improve their lives for the better. Based on the data that the authors get from the profile of the village of Tajen turns out that people who participate in the development of Temuku Aya Subak Tour is 20\% only. If the conclusion is taken because Temuku Aya Subak Tour is newly developed then the involvement of the community in this development is also not maximized.

\section{2) Socio-Cultural Impact}

The development of Temuku Aya Subak Tour does not give influence to local village customs. People continue to practice traditions or daily habits such as 
making ceremonial facilities and carrying out religious ceremonies that are ancestral cultural heritage. In the event that is in Temuku Aya Subak Tour is also certainly show the existence of local art and cultural activities of the local village, such as offering offerings in the area of Temuku Aya Subak Tour to God to beg for safety and smoothness during the existence of tourism activities. The thing that makes the tourists also feel happy is, the unique thing that only exist in Temuku Aya Subak Tour that is when new arrivals or before the start of the activity, tourists will be in a special ceremony (ritual) using offerings (segehan) intended to eliminate things negative that exist in the tourists themselves before entering the Temuku Aya Subak Tour area. In addition, the Temuku Aya Subak Tour also features a traditional musical instrument that is rindik (traditional musical instrument of bamboo) they will play the instrument if there are tourists who do tourism activities. In Temuku Aya Subak Tour, tourists are also taught to make traditional Balinese hawker that is laklak (traditional snack from rice flour which contains Balinese sugar and grated coconut). In addition, there are also activities that are pounding rice with the traditional way of using wood. The event is presented to tourists, so that tourists know the cultural traditions that exist in the village and also know the activities and habits of local villagers. In addition, it can also introduce rice fields with subak system, which is a cultural heritage of ancestors and still applied until now. Even the development of tourism entering this village, the customs of local people is still running as usual. With the development of tourist attraction in this village, people still uphold the customs and also people still respect the heritage and traditions of the ancestors.

3) Environmental Impact

Because of the tourism activities in Temuku Aya Subak Tour, people cleaning the environment of Temuku Aya Subak Tour area almost every day. And cultivated to always keep the environment clean around Temuku Aya Subak Tour. Besides the clean-up activities around the environment, Temuku Aya Subak Tour also makes people aware to clean the environment around their homes or in front of their homes. Therefore, the village also has an environmental clean-up program every once a week in each Banjar. The village also has a program to buy plastic waste that has been collected by the community. With these activities, the 
cleanliness of the village environment can be maintained and awareness of the community to keep the environment will be even greater. In addition, the environmental action taken by Temuku Aya Subak Tour is by utilizing the wellproduced waste. Waste or waste generated from tourism activities in Temuku Aya Subak Tour is divided into two, plastic and organic waste. For plastic waste members take the initiative to collect and will be sold to the village. For organic waste itself is collected and contained, if it becomes fertilized later will be dabbed in the plants that are around the area of Temuku Aya Subak Tour. That thing will increase the fertility of plants that exist in the area of Temuku Aya Subak Tour. Waste from the hand wash and also the toilet already has its own safety-tank, so the waste is not disposed to the river and will not pollute the environment.

\section{CONCLUDE AND ADVICE}

\section{Conclusion}

1) Tourism potential that owned by the tourist attraction of Temuku Aya Subak Tour is natural rice fields and plantations. Tour activities at Temuku Aya Subak Tour also present cultural preservation activities and local community traditions.

2) The participation of local villagers in the development of Temuku Aya Subak Tour is as an investor, manager, waitress, cook, guide, and also marketing. All investors are included in the organizational structure of this tourist attraction and have their respective duties.

3) The economic impact by the development of Temuku Aya Subak Tour is the welfare of the involved community increases, the quality of education increases, and health increases. Socio-cultural impacts that are felt with the development of this tourist attraction is to improve the preservation of local traditions. Environmental impacts that have been felt since the development of this tourist attraction is very positive. The village environment is cleaner and more beautiful.

\section{Suggestion}

1) Temuku Aya Subak Tour tourist attraction, which is expected more to build cooperation with other fields and also promotion (marketing) should be more improved. It is also expected that the entrance gate of Temuku Aya Subak Tour 
built for tourists, so they notice when entering the area and provided a more spacious parking area for the future.

2) Expected in the future, the growing attraction presented by Temuku Aya Subak Tour can invite more and more people directly to participate either from planning, implementation, or evaluation.

3) The local community, which is expected to continue to maintain the image of the village and also the cleanliness of Tajen Village environment. In addition, also participate in maintaining the sustainability of rice fields in the tourist attraction Temuku Aya Subak Tour to stay beautiful.

\section{REFERENCES}

Adisasmita, Raharjo. 2006. Membangun Desa Partisipatif: Yogyakarta: Graha Ilmu.

Gunawan, Imam. 2016. Metode Penelitian Kualitatif. Jakarta: Bumi Aksara.

Humas STPBI. 2016. “Menguak Kemolekan Penatih Menjadi Desa Wisata". Bali Travel Newspaper, 11-24 Juni 2016.

Ismayanti. 2010. Pengantar Pariwisata. Jakarta: PT. Gramedia Widiasarana Indonesia.

Mulyadi, Mohammad. 2009. Partisipasi Masyarakat dalam Pembangunan Masyarakat Desa. Nadi Pustaka. Jakarta.

Nasution. 2003. Metode Research. Jakarta : PT. Bumi Aksara.

Oka A. Yoeti. 2002. Perencanaan dan Pengembangan Pariwisata. Jakarta : PT Pradaya Paramita.

Ointoe, Reiner Emyot, et.al. 2005. Menciptakan Gagasan, Mendorong Gerakan (Pengalaman Mendorong Partisipasi Public). Manado:Yayasan SERAT.

Pantiyasa, 2013. Metode Penelitian. Denpasar: Sekolah Tinggi Pariwisata Bali

Internasional.

Supratiwi, Fitri. 2016. Bali Kembangkan 11 desa wisata untuk 2016. Antara News, 
16 Februari 2016.

Suut Amdani. 2008. Analisis Potensi Obyek Wisata Alam Pantai di Kabupaten Gunung Kidul. Skripsi. Surakarta : Fakultas Geografi UMS. 